\title{
人エランドマークの最適配置設計法
}

田代 健 治* 太田 順* 林 遠 球* 新 井 民 夫*

\section{Design of the Optimal Arrangement of Artificial Landmarks}

\author{
Kenji Tashiro*, Jun Ota*, Yeuan C. Lin* and Tamio Arai*
}

\begin{abstract}
It is important to set landmarks when a robot needs to navigate in a certain environment and to measure its own location; however it has not been discussed well how to arrange landmarks in the optimal way until now. We, therefore, demonstrate the possibility of design of the optimal arrangement of artificial landmarks.

First, we make it clear the optimization problem with regard to the arrangement of landmarks. Second, as one example of the artificial landmarks, we introduce a signboard system. Third, we propose a methodology to evaluate arrangement of landmarks assuming an obstacled rectangular environment. Fourth, we apply the algorithm of spatial competition to the optimal arrangement of landmarks. Finally, simulation results indicate that even though our method is not global optimization approach we can obtain closely optimal and practical arrangement with the minimum number of landmarks which satisfies the necessary condition.
\end{abstract}

Key Words : Mobile Robot, Landmark, Localization, Voronoi Diagram

\section{1.はじめに}

移動ロボットによる環境探索において, 自己位置同定は基本 的な機能である，デッドレコニングは自己位置同定の主要な一 手法であるが, 累積誤差のため, その信頼性は走行距離が増え るに従って低下する.

この問題を解決するため，デッドレコニングを補う機能とし てランドマークを観測する画像センサを搭載した移動ロボット が開発されている $[1] 〜[5]$. ロボットの自律性が要求される ならば，ロボット自身が環境内の特徵物（電灯やスプリンクラ 一等）を選択して情報を抽出しなければならない. しかし，予 め環境内に情報を得やすいように単純な設計の人工ランドマー クを設置するならば，自己位置の測定は高速で信頼性の高いも のとなる、これは，移動ロボット側の負担を環境が負担したと 考えてもよい. このような，環境側のアプローチとなる研究 は，主に人工ランドマークの開発に限定されてきた。即ち，単 純な設計で効率の良いランドマークが，これまで幾つか開発さ れてきた(例えば文献 $[6])$. しかしそのように開発されたラン ドマークを配置する手法はこれまで殆ど議論されていない. 小 森谷 $[7]$ は，周囲にある多数のランドマークから最も有用なも のを選択する方法論を提案したが, そこではランドマークの数

原稿受付 1995 年 7 月 17 日

*東京大学工学系研究料

*The Graduate school of engineering, University of Tokyo
とその配置は与えられたものとしている.

筆者らは，人エランドマークの 1 例として新井らの提案した サインボートシステム $[8]$ を用いることにより，ランドマーク の最適配置法について議論を進める. 1 つサインボードは 4 つの LED（Fig. 1）を持ち, その 2 次元の画像デー夕は移動口 ボット上に搭載された CCD カメラによって得られる. 故に, 移動ロボットはランドマークとの姿勢を得る.

2 章では, ランドマーク配置問題を最適化問題の 1 つとして 明確に定義する．３章では配置されたランドマークの評価手法 について，4章ではランドマークの最適配置を設計するアルゴ リズムを示す.

\section{2. ランドマーク配置最適化問題の定義}

種々の人エランドマークが存在するが，本論では相対位置・ 姿勢を計測可能な人工物に限定する。また移動ロボットは，通

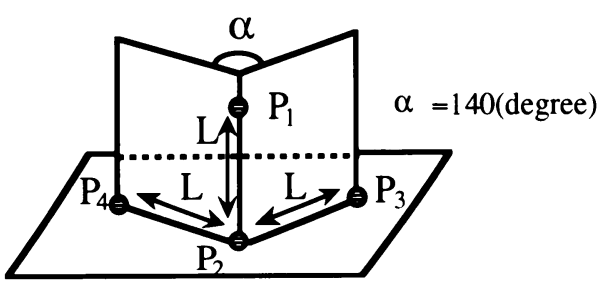

Fig. 1 Overview of a signboard unit 
常デッドレコニングで自己位置同定を行っており，適当な距離 を走行すると人エランドマークを観測することにより自己位置 の誤差を補正するものとする。このとき，誤差を補正するため に移動ロボットがランドマークを観測しようとする場所が， ラ ンドマークの観測に適していない事態が考えられる.

ランドマーク配置の最適化問題の設定を明らかにする. 移動 ロボットの自己位置は, 環境内の任意の点で同定可能であり, かつある精度以上で同定可能であることが必要である．別の言 い方をすれば，自己位置の䛊差の上限值が設計仕様として重要 である.さらに，ランドマークの設置コストを考慮すれば， ラ ンドマークの数は出来るだけ少ない方がよい. 従って, ランド マーク配置の最適化問題は以下のように定義できる.

ランドマーク配置の最適化問題とは，「環境内のどの点でラ ンドマークを観測したとしても，自己位置同定がある精度以上 で可能であるような, 最少個数のランドマーク配置を探索する こと」である.

ただし，我々は移動ロボットが常時ランドマークを観測して いると仮定しているわけではないことに注意しなければならな い. デッドレコニングの累積䛊差をキャンセルすべく移動ロボ ットが環境内のどの点でランドマークを観測したとしても, 自 己位置がある精度以上で補正されることを保証するのが, 最適 配置である.

具体的な最適化法を，次の 2 段階より構成する.

第 1 段階では，ランドマークの数を固定して，ランドマーク の配置のみを変化させて, 環境内の自己位置誤差の最大値を最 小化する. ランドマークの数を変えて, 各ランドマーク数に対 応する配置を求める。

第 2 段階では，設計仕様で環境内の最大位置誤差に関して上 限值が与えられるとすると，それを満たすような最少のランド マーク数とその配置を先の各ランドマーク数に対応した配置よ り決定する.

このように我々の目的は, ある環境と最大位置誤差の上限值 が与えられたときに，最低でも幾つランドマークが必要なの か，そして如何なる配置にすべきなのかを決定することであ る.

\section{3. ランドマークモデル}

\section{1 サインボード}

相対位置・姿勢を同定可能な人工ランドマークの 1 つとし て, 本論ではサインボード [6]を採用し, 配置手法の議論を進 める. ただし, サインボード以外のランドマークを採用したと しても, 配置されたランドマークの評価手法や 4 章で述べる設 計手法の一般性は失わない.

サインボードを観測することにより，移動ロボットは CCD カメラの画像を通して, 迅速にかつ正確に自己位置を同定す る.

サインボードュニットは Fig. 1 に示されるように, 2 つの平 板をある角度 $\alpha て ゙$ 合わせた構造をしており, 一定長 $L て ゙$ 隔てら れた 4 つの LED を持つ. 角度 $\alpha$ は, 測定した相対回転角 $\theta$ の 標準偏差 $\sigma_{\theta}$ を最小化するように最適化し， $\alpha=140$ [degree] と している[6].

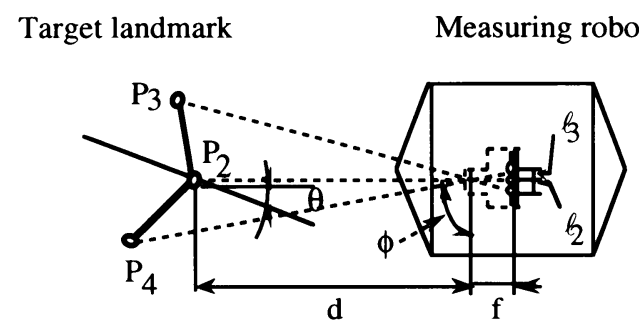

Fig. 2 Relationship between a signboard and a measuring robot

以降では，サインボードュニットを単にサインボードと呼ぶ こととし, 最適配置設計に於いては 1 つのランドマークとして 使用する.

\section{2 相対位置・姿勢の計算手法}

ロボットは，観測対象となるサインボードとの相対位置・姿 勢を計算する. 相対姿勢は, 距離 $d$, 方向 $\phi$, 回転角 $\theta$ の 3 変数で定義される（Fig. 2).

対象ランドマークが $\theta$ 回転しても, 垂線 $\mathrm{P}_{1} \mathrm{P}_{2}$ の像長は一定 に保たれる。像長 $\mathrm{P}_{1} \mathrm{P}_{2}$ は距離 $d$ に反比例することから， $\mathrm{d}$ が 計算可能である.

$\mathrm{P}_{2} \mathrm{P}_{3}, \mathrm{P}_{2} \mathrm{P}_{4}$ の像長 $l_{2}, l_{3}$ の比は相対回転角 $\theta$ に依存する. カメラ像面と対象ランドマークの方向とがなす角 $\phi$ は, 像上 におけるサインボードュニットと，像の中心点との距離を計算 することで得られる。

\section{3 サインボードの誤差解析}

自己位置同定で生ずる測定誤差の要因としては, CCD カメ ラによる量子化誤差と，ランドマークの設置誤差が考えられる が, ここでは CCD カメラの量子化誤差のみを考慮する. 移動 ロボットによって測定されたサインボードとの相対距離 $d$ と 相対回転角 $\theta$ の誤差をそれぞれ $e_{d}, e_{\theta}$ と記述する.すなわ ち,

$$
d=\underline{d}+e_{d}, \theta=\underline{\theta}+e_{\theta}
$$

ここで, $\underline{d}, \underline{\theta}$ は $d$ および $\theta$ の真值である. サインボード の誤差解析を以下で行う. $e_{d}$ と定義される相対距離 $d$ の測定 誤差は次式で表される.

$$
e_{d}=\frac{d^{2}}{L f} e_{1}
$$

ここで, $e_{1}$ は $\mathrm{P}_{1} \mathrm{P}_{2}$ の像長 $l_{1}$ の量子化誤差, $L$ は LED 間の距 離, $f$ はCCD カメラの焦点距離である.

式 ( 2 ) から, 距離の量子化誤差は, 相対距離 $d$ が一定とな る条件下では LED 間距離 $L$ に反比例することが分かる. $e_{\theta}$ と定義される相対回転角 $\theta$ の測定誤差は次のように表され る。

$$
e_{\theta}=\sqrt{\left(\frac{\partial \theta}{\partial l_{2}}\right)^{2} e_{2}^{2}+\left(\frac{\partial \theta}{\partial l_{3}}\right)^{2} e_{3}^{2}}
$$

ここで, $e_{2}, e_{3}$ はそれぞれ $\mathrm{P}_{2} \mathrm{P}_{3}, \mathrm{P}_{2} \mathrm{P}_{4}$ の像長 $l_{2}, l_{3}$ (Fig. 2) の量子化誤差である

上式で示される $e_{\theta}$ の計算アルゴリズムは，観測に成功した LED の数に依存する. 式( 3 )の值は以下の場合においてそれ ぞれ決定される。

( a ) 全ての LED $\left(\mathrm{P}_{1}, \mathrm{P}_{2}, \mathrm{P}_{3}, \mathrm{P}_{4}\right)$ が観測される場合 
$\frac{\partial \theta}{\partial l_{2}}=\frac{\left(l_{3}+f \cot \phi-l_{3} \cos \alpha\right) G_{1}+\left(f+l_{3} \sin \alpha\right) G_{2}}{G_{1}^{2}+G_{2}^{2}}$

$$
\frac{\partial \theta}{\partial l_{3}}=\frac{G_{2 d} G_{1}-G_{1 d} G_{2}}{G_{1}^{2}+G_{2}^{2}}
$$

ここで， $G_{1}, G_{2}, G_{1 d}, G_{2 d}$ は次のように定義される.

$G_{1}=l_{2} f+l_{3} f \cos \alpha+\left(l_{2}-f \cot \phi\right) l_{3} \sin \alpha$

$G_{2}=l_{2} l_{3}+l_{2} f \cot \phi+l_{3} f \sin \alpha-\left(l_{2}-f \cot \phi\right) l_{3} \cos \alpha$

$G_{1 d}=f \cos \alpha+\left(l_{2}-f \cot \phi\right) \sin \alpha$

$G_{2 d}=l_{2}+f \sin \alpha-\left(l_{2}-f \cot \phi\right) \cos \alpha$

(b) $\mathrm{P}_{1}, \mathrm{P}_{2}, \mathrm{P}_{3}$ の 3 点が観測可能で, $\mathrm{P}_{4}$ が観測不能の場合

$$
\sigma_{\theta}=\frac{\lambda \sqrt{3}}{6}\left|\frac{\partial \theta}{\partial l_{2}}\right|
$$

ここで

$$
\frac{\partial \theta}{\partial l_{2}}=\left\{\begin{array}{c}
\frac{1}{l_{u}^{2}+f^{2}}\left\{\frac{d\left(l_{u}^{2}+f^{2}+l_{2} l_{u}\right)}{\sqrt{L^{2}\left(l_{u}^{2}+f^{2}\right)-d^{2} l_{2}^{2}}}+f\right\} \\
\text { when } \theta+\sin ^{-1} \frac{l_{2}}{\sqrt{f^{2}+l_{2}^{2}}} \geq 0 \\
\frac{1}{l_{u}^{2}+f^{2}}\left\{-\frac{d\left(l_{u}^{2}+f^{2}+l_{2} l_{u}\right)}{\sqrt{L^{2}\left(l_{u}^{2}+f^{2}\right)-d^{2} l_{2}^{2}}}+f\right\} \\
\text { when } \theta+\sin ^{-1} \frac{l_{2}}{\sqrt{f^{2}+l_{2}^{2}}}<0
\end{array}\right.
$$

ただし， $l_{u}=f \cot \phi-l_{2} \lambda$ は, $\mathrm{CCD}$ カメラの一画素長を意味 する.

(c ) $\mathrm{P}_{1}, \mathrm{P}_{2}, \mathrm{P}_{4}$ の 3 点が観測可能で, $\mathrm{P}_{3}$ が観測不能の場 合も (b) と同様に $\frac{\partial \theta}{\partial l_{1}}$ を計算する.

これまで $e_{d}$ と $e_{\theta}$ の定式化を行ってきた，2章では，移動口 ボットがランドマークを観測して自己位置を補正する場合，環 境内のどの位置に存在しても常にある一定值以内の測定誤差を 保証することが重要であると述べた。したがって実際には，相 対距離 $d$ と相対回転角 $\theta$ の最大測定誤差 $e_{d, \max } e_{\theta, \max }$ を考慮し なければならない. $e_{1}, e_{2}, e_{3}$ の最大值を $e_{1, \max }, e_{2, \max }, e_{3, \max }$ と表記すると, $e_{d, \max } e_{\theta, \max }$ は式(1)(2)に $e_{1}=e_{1, \max ,} e_{2}=e_{2, \max ,}$ $e_{3}=e_{3, \max }$ を代入して得られる. $e_{1}, e_{2}, e_{3}$ を何れも $U(-\lambda, \lambda)$ なる一様分布と仮定できる. $e_{1, \max }=e_{2, \max }=e_{3, \max }=\lambda$ と仮定 すると，式（1）（2）は次のように書き換えられる.

$$
\begin{gathered}
e_{d, \max }=\frac{d^{2}}{L f} \lambda \\
e_{\theta, \max }=\lambda \sqrt{\left(\frac{\partial \theta}{\partial l_{2}}\right)^{2}+\left(\frac{\partial \theta}{\partial l_{3}}\right)^{2}}
\end{gathered}
$$

次に，平面内における $d$ と $\theta$ の誤差の広がりを調べる. $e_{d, \max }$ の誤差分布図を Fig. $3(\mathrm{a})$ に, $e_{\theta, \max }$ の誤差分布図を (b)に示す. Fig. 3 の各曲線は，等誤差点を結ぶことにより得 られる等位曲線を表す。 $e_{d, \max }$ は点 $\mathrm{P}_{1}\left(\mathrm{P}_{2}\right)$ を中心に同心円状 に広がり, 無指向性と言える. $e_{\theta, \max }$ は指向性を持ち, 不連続 点が存在する.これは， $e_{\theta}$ の計算アルゴリズムが観測された LED の数に依存することに起因している（Eq.4〜7).これら の不連続点は, 全ての $\operatorname{LED}\left(\mathrm{P}_{1}, \mathrm{P}_{2}, \mathrm{P}_{3}, \mathrm{P}_{4}\right)$ が観測可能な場 合と 3 つの LED のみが観測可能な場合の境界線を形成する.

不連続点における誤差の大きさの比較により，3点観測可能な 場合より 4 点観測可能な場合の方が計測精度が良好であること がわかる．ここで，ランドマーク以外の障害物による遮蔽はな いものとし, CCD カメラの画素長 $\lambda=15[\mu \mathrm{m}]$, 焦点距離 $f=$

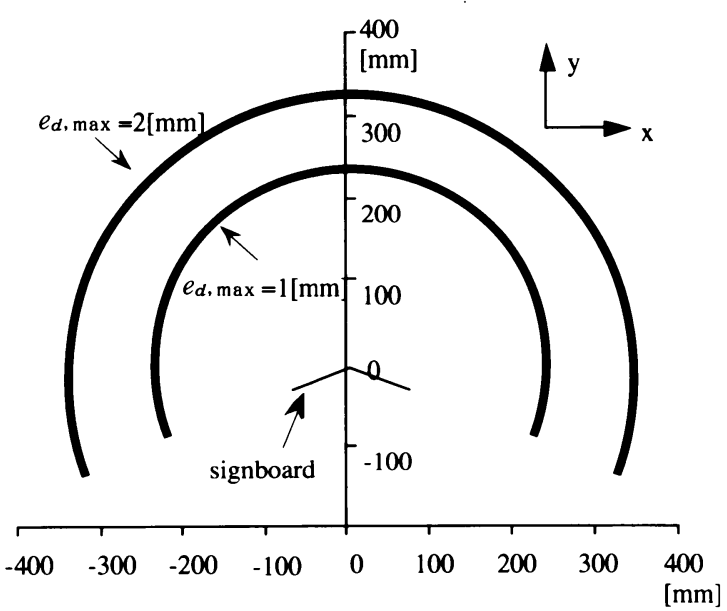

(a) $e_{d, \max }$ : relative position error

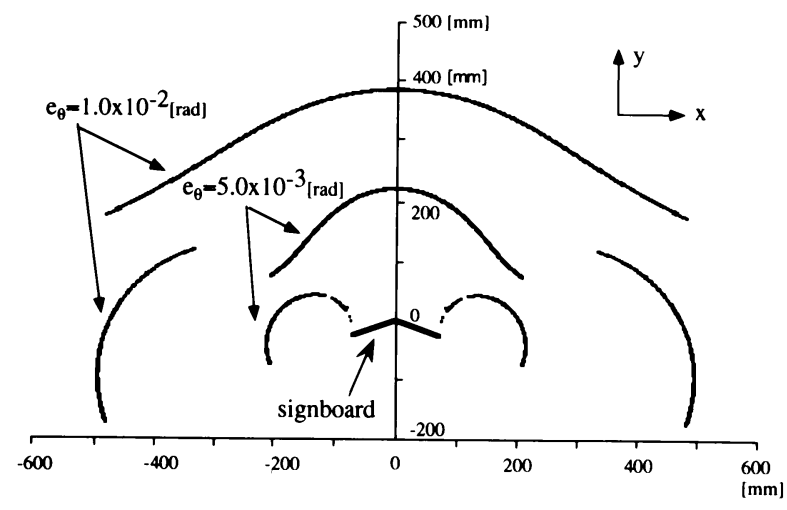

(b) $e_{\theta}$ : relative orientation error

Fig. 3 Geographical distribution of error

$12[\mathrm{~mm}]$, 方向 $\phi=90[$ degree $], \mathrm{LED}$ 間の距離 $L=7[\mathrm{~cm}]$ と した.

\section{4. 配置されたランドマークの評価手法}

\section{1 位置誤差 $L e$ の定義}

移動ロボットはランドマークを観測することにより相対位置 を計算するが, 必然的に誤差を含む。 その誤差は, CCD カメ ラによる量子化誤差と, ランドマークの設置誤差が考えられる が，ここでは CCD カメラの量子化誤差のみを考慮し, 自己位 置同定で生じる誤差を位置誤差として以下のように定義する。

Fig. 4 亿示すように，移動ロボットがランドマーク Lan $(i)$ を測定して自己位置を計算する場合を想定する．今， Lan $(i)$ の点光源 $\mathrm{P}_{1}$ を原点とする極座標系で表現された, 図中の点 $\mathrm{R}(d, \theta)$ に移動ロボットが位置するものとする．移動ロボット はランドマーク $\operatorname{Lan}(i)$ を観測することにより, 相対距離 $d$, 相対回転角 $\theta$, 相対方向 $\phi$ を計算する（Fig. 2)，単純化のた め, 方向 $\phi$ は常に 90 度とする.

ロボットが実際に位置している点を $\mathrm{R}(\underline{d}, \underline{\theta})$ とし，ロボット がランドマークを観測することで計算した自己位置を $\mathrm{R}_{m}(d$, $\theta)$ とする. $\mathrm{R}$ と $\mathrm{R}_{m}$ の関係は式 (1)で記述される.

$e_{d}, e_{\theta}$ の最大值 $e_{d, \max }, e_{\theta, \max }$ を用いると, 移動ロボットが 同定する自己位置は Fig. 4 に示される扇型 KLMN 内部の点で 


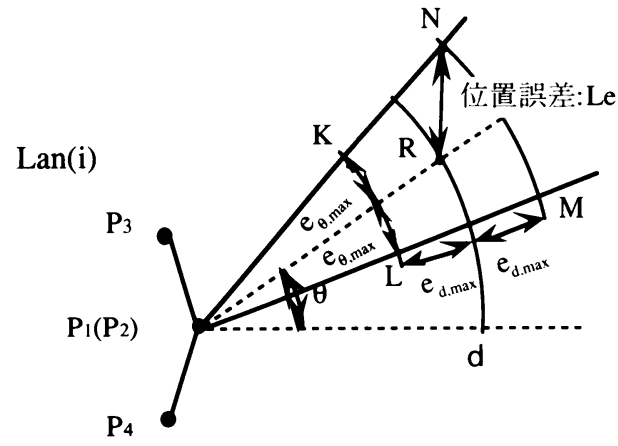

Fig. 4 Definition of location error at $\mathrm{R}(d, \theta)$

あると言える、ロボットが実際に位置する点 $\mathrm{R}$ からの最大偏 差は点 $\mathrm{N}$ または点 $\mathrm{M}$ に位置する場合であるから，この最大偏 差長を点 Rにおける位置誤差と定義する (Fig. 4). すなわち位 置誤差を $L_{e}$ と表記すると， $L_{e}$ は式(10)で表される.

$$
\begin{aligned}
L_{e} & \equiv|R N| \\
& =\sqrt{\left\{\left(d+e_{d, \max }\right) \cos \left(\theta+e_{\theta, \max }\right)-d \cos \theta\right\}^{2}} \\
& \times\left\{\left(d+e_{d, \max }\right) \sin \left(\theta+e_{\theta, \max }\right)-d \sin \theta\right\}^{2}
\end{aligned}
$$

環境に複数のランドマークが置かれている場合，移動ロボッ トは，測定点 R から観測可能な，最小の位置誤差を与えるラ ンドマークを選択できるものとし，このランドマークが与える 位置誤差を点 $\mathrm{R}$ における $L_{e}$ として採用する，この仮定は，移 動ロボットがランドマークを観測して自己位置を補正したい 時，最適なランドマークを 1 つだけ選択できることを意味して いる.この手法はアルゴリズムが単純であり，リアル夕イム性 に優れたものと考えられる. 移動ロボットが如何にして最適な ランドマークを知りうるかという問題があるが，どの位置では どのランドマークを選択すべきかを記述したマップを作成し， 移動ロボットに保持させることで可能となる．このマップはボ ロノイ図の応用として 4.2 節で議論する.

さらに，ある位置で障害物の遮蔽などによりどのランドマー クも観測出来ない場合は, その位置の $L_{e}$ の値は無限大とす る.

\section{2 領域の分割}

前節において, 移動ロボットがランドマークを観測する時, 唯一の最適なランドマークを選択するものと仮定した．その結 果, 環境は, ある特定のランドマークが観測に最適となる点の 集合からなる有限個の小領域に分割できる。この領域分割は,

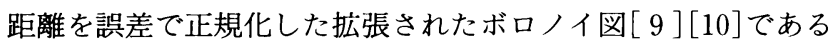
と解釈できる。本節では，その分割手法を示す.

環境内の任意の点において，観測可能な全てのランドマーク について式(10)から位置誤差 $L_{e}$ を計算する．その中で最小の $L_{e}$ をこの観測点における位置誤差とし，この位置誤差を与え るランドマークがこの点における最適ランドマークとなる。こ の手順を全ての点について行なうと, 環境はランドマーク $i$ が 最適な領域，ランドマークjが最適な領域…ととうように, 有限個の小領域に分割される. 小領域の数は，ランドマークの 数と一致しないことに注意されたい.

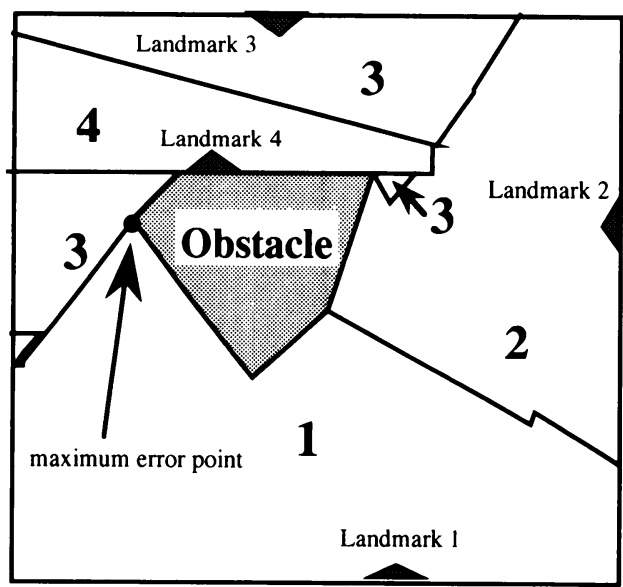

The environment is $25[\mathrm{~m}] \times 25[\mathrm{~m}]$ square Maximum position error $\mathrm{M}_{\mathrm{e}}=1.22[\mathrm{~m}]$

Fig. 5 One example of the spatial tessellations

Fig. 5 に，ランドマークが配置された場合の領域分割の一例 を示す．環境は $25 \times 25[\mathrm{~m}]$ の正方形領域であり，4つのランド マークが配置されている，小領域に記入されている番号は，移 動ロボットがその領域内部にいる時に観測すべきランドマーク 番号を示している. 領域境界線が直線とならないのは，相対回 転角 $d$ の測定誤差 $e_{d}$ の分布が指向性を持つためである (Fig. 3 (b)).

\section{3 配置されたランドマークの評価手法}

本節では，ランドマーク配置が与えられた場合の評価手法を 提案する. 4.2 節で述べたように，環境は多数の小領域に分割 され，任意の点で観測すべきランドマークと位置誤差の值が決 定されている.

我々に与えられた設計要求は，環境内の任意の点で，位置誤 差の値が予め設定された上限以下になることであった。 したが って本論では，環境内の位置誤差 $L_{e}$ の最大值をランドマーク 配置の評価指標とし，これを $M_{e}$ と表記する．例えば Fig. 5 に おいては，位置誤差の最大点は黒塗の点であり，したがって配 置の評価値は $M_{e}=1.22[\mathrm{~m}]$ と表現する.

\section{5. 最適ランドマーク配置の設計手法}

\section{1 適用環境の設定}

以下の環境を想定する。

（1）ロボットの探索空間となる環境は 2 次元平面で，その 内部に障害物が存在する.

（2）全てのランドマークは環境境界上，または障害物面に 接した状態でのみ設置可能である.

仮定 $(2)$ は, 計算量の軽滅, ランドマーク設置の容易性, ラ ンドマークを移動ロボットの走行の障害にならないようにす る，という観点から設定した。

\section{2 配置の設計の定式化}

最適配置を得るアルゴリズムを，次の 2 段階より構成する。 第 1 段階では, ランドマークの数を固定し，配置のみを変化さ せて環境内の位置誤差の最大値 $M_{e}$ を最小化する．この段階 
は，式(11)で表される.ランドマーク数を $n$ 個として, 評価 值 $M_{e}$ を最小化し，その収束值を $C_{v}(n)$ とする. $n$ を変化させ て同様の操作を行うと，各ランドマーク数に対応する $C_{v}(n)\{n$ $=1,2,3, \cdots\}$ を求めることが出来る.

$$
\begin{aligned}
& M_{e}(n) \equiv \max \left\{L_{e}(x),{ }^{\forall} x \in W\right\} \rightarrow \min \\
& C_{v}(n) \equiv \min \left\{M_{e}(n) \mid n \text { is fixed }\right\}
\end{aligned}
$$

ここで

$W:$ 移動ロボットの作業環境

$x: W$ 内の点

$n:$ ランドマークの個数

第 2 段階では，位置誤差の上限值 $K$ が要求されたとき， $K$ を満足する最小個数のランドマーク配置を $C_{v}(n)\{n=1,2,3, \cdots$ ․ 可中から探索する.この過程は次式で表現できる.

$$
\min \left\{n \mid C_{v}(n) \leq K\right\}
$$

以上より，最適配置問題は式(11) (12)の 2 式で表現できる.

\section{$5.3 M e$ を最小化するアルゴリズム}

本論では，複数企業による領域競合アルゴリズム[11]を本最 適化問題に適用した。このアルゴリズムによって，ランドマー ク数を固定しつつ, 評価関数 $M_{e}$ を最小化する.

競合アルゴリズムの概要は次の通りである．ランドマーク数 を $n$ 個と固定して，ランダムにランドマークの初期配置を生 成する，次に，各ランドマークを 1 個ずつ，次に示す 3 つの方 法のうち評価値 $M_{e}$ を最も減少させる 1 つを採用して移動さ せ，この移動を収束配置が得られるまで繰り返す。

\section{戦略}

（a）現在存在している境界上を勾配方向に移動する

（b）環境内において位置誤差が最大値 $\left(M_{e}\right)$ をとる点に最 も近い環境境界または障害物面上に移動する

（c）上記いずれの場合も $M_{e}$ の現在值を減少させないなら ば，現在地に留まる

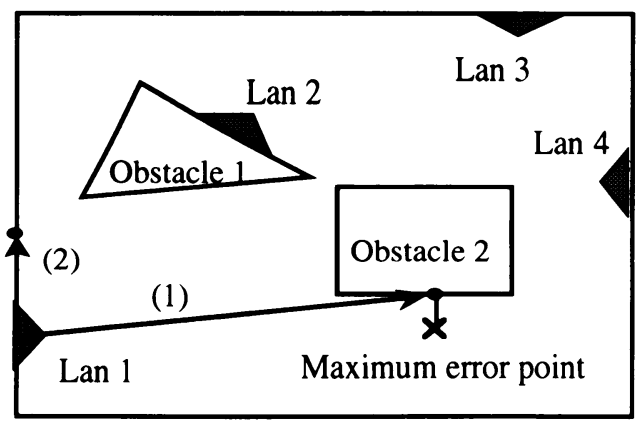

Fig. 6 Strategy to minimize the evaluation function : $M_{e}$

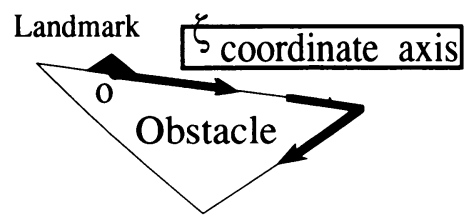

Fig. 7 Coordinate system when a landmark is shifted by strategy (a)
戦略 ( a ) を採用する場合，ランドマークの移動量は，次の様 に決定する．まず Fig.7で示されるように，環境あるいは障 害物の境界線を時計周りの向きに移動方向としてと軸を定め る. 環境内の位置誤差の最大值 $M_{e}$ を評価值として，移動すべ きランドマークの位置 $と は-\frac{\partial M_{e}}{\partial \zeta}$ だけ移動する. したがっ て, 次のランドマークの位置は, $\zeta-\frac{\partial M_{e}}{\partial \zeta}$ となる.

戦略 ( b ) を採用した場合, 移動すべきランドマークの位置 を, 現時点の位置誤差の最大值 $M_{e}$ をとる点に最近接の境界面 上に移動させる（Fig. 6)。ただし，位置誤差が無限大の領域が 存在するとき，その適当な点を $M_{e}$ の点として採用する.

戦略 $(\mathrm{a})(\mathrm{b})$ ともに現在の評価值 $M_{e}$ を隇少させない場合 は，ランドマークを現在位置に留める。これを戦略 (c)とす る.

$1 つ 1$ つのランドマークについて以上の移動を行い，全ての ランドマークの移動が終了した時，これを 1 [step] と定義す る. 評価值 $M_{e}$ が収束するまで，ステップを繰り返す.

この手法は，大域的最適化手法ではないが，総当たり探索と 比較して計算時間が短く，実用的な解を得ることができる，次 章では，シミュレーションで本手法でランドマーク配置が決定 可能であることを示す。

\section{6. シミュレーション}

\section{1 シミュレーションの目的}

ロボットの探索空間において，位置誤差の上限值が要求され た場合，それを満足する最少個数のランドマーク配置を求め る.

\section{2 シミュレーション環境の設定}

本シミュレーションでは，まずランダムにランドマークの初 期配置を発生させる。これをもとに，5.3 節で提案したアルゴ リズムを用いて，その評価値 $M_{e}$ すなわち環境内の位置誤差の 最大値を最小化する。

以下では，5.3 節の戦略 (a )を計算機上で近似計算する場合 のアルゴリズムを簡単に述べる。戦略（ａ）が選択された場合， 次の近似式を用いて勾配を決定する.

$$
\Delta \zeta_{i}=-K \frac{M_{e}\left(\zeta_{i}+d \zeta\right)-M_{e}\left(\zeta_{i}\right)}{d \zeta}, \quad \zeta_{i+1}=\zeta_{i}+\Delta \zeta_{i}
$$

ここで,

$\zeta_{i}: i$ ステップ後のランドマークの座標

$d \zeta:$ 疑似微分のための微小定数

$K:$ 係数

$\Delta \zeta_{i}:$ 最急降下方向

システムは次のように設定した

（1）環境は $10[\mathrm{~m}] \times 10[\mathrm{~m}]$ の正方形領域で，2つの障害物 が存在する (Fig. 8).

（2）サインボード LED 間の距離 $L$ は， $7[\mathrm{~cm}]$ とする

（3） $\mathrm{CCD}$ カメラに関しては，焦点距離 $f$ を $12[\mathrm{~mm}], 1$ 画素長を $7.5[\mu \mathrm{m}]$ とする.

（4）勾配については，以下のように変数を設定 


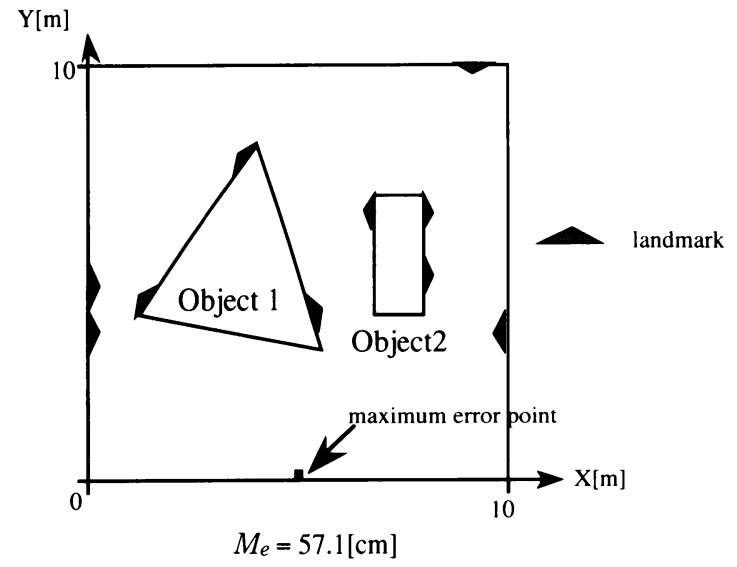

Fig. 8 Initial arrangement of 10 landmarks

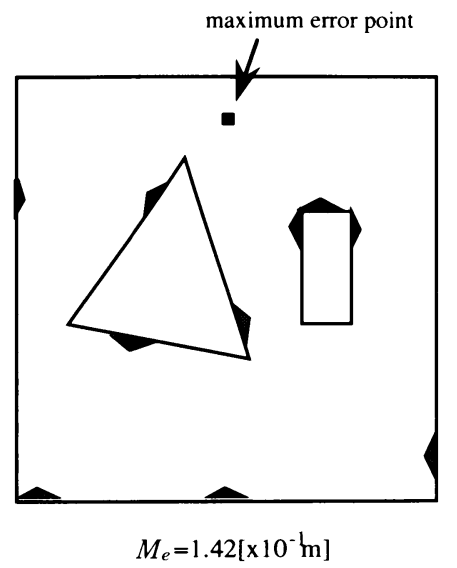

Fig. 9 Arrangement at step 15

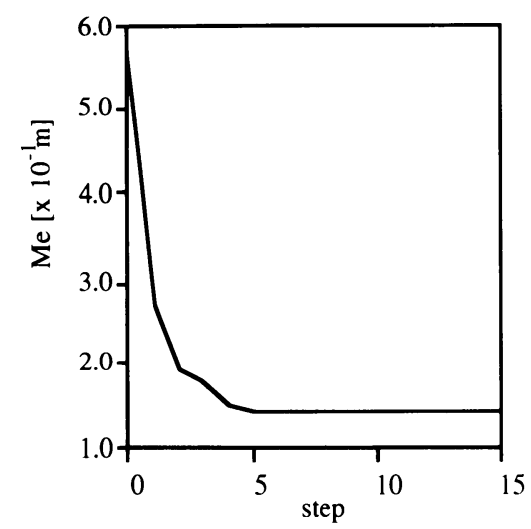

Fig. 10 Transition of the maximum location error $\left(M_{e}\right)$ in case of 10 landmarks

$$
d \zeta=0.3[\mathrm{~m}], \quad K=10.0
$$

各ランドマーク数に対応する初期配置を 5 個ランダムに発生 させた. 各初期配置について 5.3 節のアルゴリズムを用いて環 境内の最大位置誤差 $M_{e}$ を最小化する. 収束值 $C_{v}(n)$ のうち最 小であるものを採用し，この初期配置より生成した収束配置を ランドマーク数 $n$ に対応する配置とする.

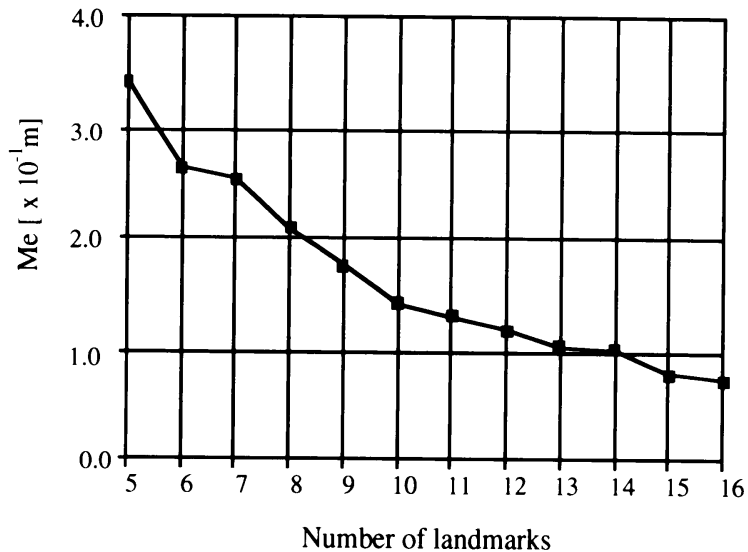

Fig. 11 Convergent value $\left(C_{v}\right)$ of $M_{e}$ for various number of landmarks

ランドマーク数 10 の場合の初期配置を Fig. 8 に示す.

6. 3 シミュレーション結果

Fig. 8 を初期配置とした時, 評価関数 $M_{e}$ はステップ数が増 加するにつれて減少する. Fig.9 は，15 ステップ後の配置で あり，この時 $M_{e}$ は $1.42 \times 10^{-1}[\mathrm{~m}] て ゙$ 収束した．Fig. 10 にス テップ毎の $M_{e}$ の遷移図を示す.

ランドマークの数を変化させて, 各個数に対して $M_{e}$ を最小 化し，収束配置を得る。これらの操作の集計結果を Fig. 11 に 示す．ランドマークの個数が増大するほど，誤差が減少する傾 向が見られる。なお，この単調減少の性質は，初期配置をラン ダムに決定する場合には常に保証されるものではない.しかし ながら, ランドマーク数 $n$ の場合の初期配置として,「ランド マーク数 $n-1$ の際の準最適配置にもう一つのランドマークを ランダムに設置した初期配置」をも採用することにより，この 問題は解決されると考えられる. また，初期配置に対する $M_{e}$ の值は, 得られた準最適配置の 2〜3 倍程度とかなりばらつき が大きかった.このことより，初期配置の個数を増加させるこ とでより適切な配置が得られる可能性があることがわかるが, ここでは，計算時間の観点から配置個数を 5 と限定した.

Fig. 11 から，環境内の位置誤差の上限值が例えば $3.00 \times$ $10^{-1}[\mathrm{~m}]$ と設定された場合，少なくとも 6 個のランドマークが 必要であり， $1.50 \times 10^{-1}[\mathrm{~m}]$ と設定された場合は 10 個のラン ドマークが必要であることがわかる。また，位置誤差の上限値 を $1.50 \times 10^{-1}[\mathrm{~m}]$ とした場合の準最適配置は，Fig. 9 の配置 と言える. 補足であるが，4個以下のランドマークではどのよ うな配置をしても $M_{e}=\infty$ なる領域が存在する.すなわち， ど のランドマークも観測できない領域がある.

\section{7. 結}

\section{論}

最適なランドマーク配置を設計するための方法論を確立する ため，本論では以下の手順で議論を進めた.

まず，環境にランドマークを配置する問題を最適化問題とし て明確に定義した。次にサインボードシステムとその誤差解析 を紹介した，その後，環境内に配置されたランドマークの評価 方法を示した. さらに，この最適化問題を定式化し，ランドマ ークの準最適配置を得るためのアルゴリズムを示した。最後 
田代健治太田順

に, コンピュータシミュレーションを行なうことで, 環境内の 位置誤差の上限值が与えられた時に，それを満足する最少個数 のランドマーク配置を求めることが可能であることを示し，準 最適配置の設計法を示唆した.

本論では，人工ランドマークの 1 例としてサインボードシス テムを用いたが，他のランドマークでも本手法により準最適配 置の設計が可能である。 また, 移動ロボットが複数個のランド マークを利用して自己位置同定すると仮定しても，4 章で定義 した $L_{e}$ を再考する必要があるものの，本論で提案した手法を 用いてランドマークの配置設計が可能である.

\section{参 考 文 献}

[1 ] 斉, 大川 : “移動ロボットの誘導のための立体標識”, 日本ロボット学 会誌, vol. 9, no. 4, pp. 129-136, 1991.

[2 ] 藤原, 米澤, 津村 : “画像情報を利用した移動体の位置姿勢計測法”, シ ステム制御情報学会論文誌, vol. 3, no. 4, pp. 110-117, 1990.

[3] T. D' Orazio, M. Ianigro and E. Stella and A. Dstante: "Self Location of a Mobile Robot Using Visual Landmarks," Proc. of IEEE/RSJ Int. Conf. on Intell. Robots and Systems, pp. 1869-1874, 1992.

[4 ] Christian Hock: "Landmark Navigation with ATHENE," Fifth Int. Conf. on Advanced Robotics (91 ICAR.), vol. 2, pp. 1099-1104,

1991.

[5] M. Hannu and K. Kari: "Navigation of Outdoor Mobile Robots Using Dead Reckoning and Visually Detected Landmarks," Fifth Int. Conf. on Advanced Robotics (91 ICAR.), vol.2, pp. 10511056, 1991.

[6] Jaw H. Kim and Hyung S. Cho: "Experimental investigation for the estimation of a mobile robot's position by linear scanning of a landmark," Robotics and Autonomous Systems, vol. 13, pp. 3951, 1994.

[7] K. Komoriya, E. Oyama and K. Tani : "Planning of Landmark Measurement for the Navigation of a Mobile Robot," Proc. of IEEE/RSJ Int. Conf. on Intell. Robots and Systems, pp. 1476-1481, 1992.

[ 8 ] 新井, 木村, 前田, 太田, 梅田 : “移動ロボット相互の位置・姿勢実時間 計測システムの開発”, 日本ロボット学会誌, vol. 12 , no. 3 , pp. 472478, 1994.

[9] A. Okabe, B. Boots and K. Sugihara: "Spatial Tessellations: Concepts and Applications of Voronoi Diagrams," John Wiley (Chichester), 1992.

[10] A. Okabe and F. Miki: "A conditional nearest-neighbor spatial association measure for the analysis of conditional locational independence," Environment and Planning A, vol. 16, pp. 107-114, 1984

[11] A. Okabe and A. Suzuki : "Stability of spatial competition for a large number of firms on a bounded two-dimensional space," Environment and Planning A, vol. 19, pp. 1067-1082, 1987.
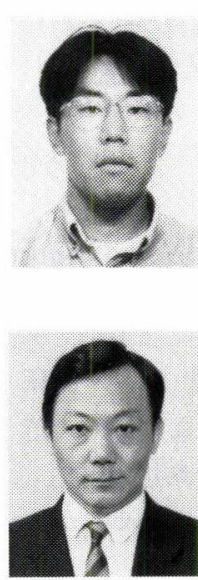

田代健治（Kenji Tashiro）

1970 年 6 月 28 日生. 1994 年東京大学工学部精密 機械工学科卒業. 現在, 同修士課程在学中. 移動 ロボットのための環境設計の研究に従事. 1995 年 カリフォルニア大学バークレー校電気工学科に文 部省国際交流制度交換生として留学. 精密工学 会, IEEE 学生会員.

(日本ロポット学会学生会員)

林 遠球 (Yeuan Chyou Lin)

1957 年 3 月 20 日生. 1986 年台湾中原大学工学部 機械工学専攻修士課程修了. 1992 年台湾交通大学 工学部制御研究科博士課程中退. 1982 1993 年 (株)三菱電機台湾支社に勤務．現在，東京大学大 学院工学系研究科精密機械工学専攻博士課程在学 中.ロボティクス, 特にロボットビジョンの研究 に従事，精密工学会，IEEE 会員.

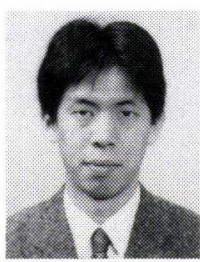

太田 順 (Jun Ota)

1965 年 2 月 19 日生. 1989 年東京大学工学系大学 院精密機械工学専攻修士課程修了. 同年新日本製 鉄 (株) 入社. 1991 年東京大学工学部助手, 1994 年 同講師. 1996 年東京大学工学系研究科助教授. 複 数台の移動ロボットの動作計画, 作業計画, 協調 制御の研究に従事. 博士(工学)。精密工学会,

IEEE 会員.

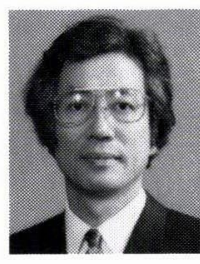

（日本ロボット学会正会員）

新井民夫（Tamio Arai）

1947 年 8 月 4 日生. 1970 年東京大学工学部精密機 械工学科卒業, 1977 年同博士課程修了. 工学博 土. 1987 年東京大学工学部精密機械工学科教授. 1979 年英国エディンバラ大学人工知能学科研究 員. 産業用ロボット言語の標準化活動を推進.自 動組立，移動ロボットなどの研究に従事。自動化 推進協会会長.

(日本ロボット学会正会員) 